\title{
PENGARUH EFEKTIVITAS MANAJERIAL, SELF-EFFICACY, STRES KERJA DAN MOTIVASI KERJA TERHADAP KINERJA DOSEN KEBIDANAN DI PROVINSI LAMPUNG
}

\author{
Sudarmi \\ Program Doktor Manajemen Pendidikan Pascasarjana \\ Universitas Negeri Jakarta \\ (yang bersangkutan Dosen Tetap Poltekkes Tanjungkarang, yang mengambil S3 di UNJ) \\ Email: Sudarmi_65@yahoo.com
}

\begin{abstract}
The objective of this research is to explore the effect of managerial effectiveness, self-efficacy, job stress and work motivation on the performance of midwifery lecturer in Lampung Province. This research used a quantitative survey method. The data was collected with questionnaires and analyzed using path analysis technique. population of the research study midwifery lecturer of province Lampung totaling 167 lecturer, sampled 118 respondents sampling technique with proportional random sampling method.The results of this research: the managerial effectiveness of a direct positive effect on performance, self-efficacy of a direct positive effect on performance, work stress of a direct negative effect on performance, work motivation of a direct positive effect on performance, managerial effectiveness direct negative effect on job stres, self-efficacy direct negative effect on job stress, managerial effectiveness of direct positive effect on work motivation, self-efficacy positive direct effect on work motivation and work stress and negative direct effect on work motivation
\end{abstract}

Keywords: Performance, managerial effectiveness, self-efficacy, job stress and work motivation.

Abstrak: Tujuan dari penelitian ini adalah untuk mengetahui pengaruh efektivitas manajerial, self-efficacy, stres kerja dan motivasi kerja terhadap kinerja dosen kebidanan di Provinsi Lampung. Penelitian ini menggunakan metode survei kuantitatif. Pengumpulan data dilakukan dengan kuesioner dan dianalisis menggunakan teknik analisis jalur. populasi dosen penelitian kebidanan provinsi Lampung sebesar 167 dosen, sampel 118 responden teknik pengambilan sampel dengan hasil pengambilan sampel acak proporsional method.The penelitian ini: efektivitas manajerial efek positif langsung pada kinerja, self-efficacy dari efek positif langsung kinerja, stres kerja dari efek negatif langsung terhadap kinerja, motivasi efek positif langsung pada kinerja, efektivitas manajerial efek negatif langsung terhadap stres kerja, self-efficacy efek negatif langsung terhadap stres kerja, efektivitas manajerial berpengaruh positif langsung pada pekerjaan bekerja motivasi, self-efficacy yang positif secara langsung motivasi kerja dan stres kerja dan efek negatif langsung terhadap motivasi kerja.

Kata Kunci: Kinerja, efektivitas manajerial, self-efficacy, stres kerja dan motivasi kerja. 


\section{PENDAHULUAN}

Program Melinium Devolopment Golds (MDGs) bidang kesehatan, salah satu target indikator yang akan di capai pada tahun 2015 adalah menurunnya Angka Kematian Ibu $(\mathrm{AKI})=102 / 100.000$ kelahiran hidup dan Angka Kematian Bayi (AKB) 34/1000. Upaya pencapaian target target MDGs tersebut diperlukan SDM bidang kesehatan, diantaranya adalah tenaga bidan. Bidan sebagai tenaga kesehatan dituntut memberikan pelayanan yang berkualitas sesuai standar yang telah ditetapkan, sehingga diharapkan dapat menurunkan Angka Kematian Ibu (AKI) dan Angka Kematian Bayi (AKB).

Strategi untuk mencapai peningkatan profesional SDM kesehatan, maka diperlukan peningkatan kualitas tenaga kesehatan, baik melalui pengembangan pendidikan tenaga kesehatan yang tersedia juga pengembangan pendidikan bagi calon tenaga kesehatan yang akan dihasilkan.

Hasil pengamatan awal penulis diprovinsi lampung terdapat 14 lembaga pendidikan DIII kebidanan, hasil akreditasi 14 Program Studi kebidanan, ternyata baru 5 program studi Kebidanan yang telah terakreditasi oleh BAN-PT selebihnya hanya terakridaitasi oleh Badan Akriditasi Dep-Kes. Jumlah dosen pada tahun 2011 dari 36 dosen kebidanan di Poltekkes Tanjungkarang, 30 dosen berlatar belakang pendidikan S2 dan masih ada 6 dosen yang hanya berlatar belakang pendidikan DIV atau S1.

Kinerja adalah unjuk kerja yang ditunjukkan oleh pegawai terhadap pekerjaannya, ada beberapa faktor yang mempengaruhi kinerja, meliputi: faktor individual, faktor ekonomi, faktor konteks organisasi, dan faktor karakteristik pekerjaan. Selain itu faktor keperibadian disebut sebagai faktor lima besar (the big five factors) juga berpengaruh, kelima faktor tersebut adalah keterbukaan (extroversion), ketelitian (conscientiousness), kestabilan emosi (emotional stability), kemampuan menerima pendapat (agreeableness), dan keterbukaan terhadap pengalaman baru (openness to experience).

Faktor individual adalah lingkungan yang ada didalam diri karyawan diantaranya adalah keyakinan diri (self-efficacy) yang dimiliki karyawan untuk melaksanakan tugas yang menantang, selain itu motivasi dan stres merupakan faktor yang berpengaruh terhadap keberhasilan seorang karyawan dalam bekerja.

Untuk menentukan kinerja karyawan melalui penilaian kerja, bentuk pengukuran dapat secara kuantitatif ataupun dalam pengamatan kualitatif pengukuran tidak hanya pada hasil-hasil phisik saja, namun juga dapat diarahkan pada sikap dan prilaku setiap individu, melalui penelitian ini diharapkan dapat menemukan pokok permasalahan, mengapa kinerja dosen kebidanan di Provinsi lampung belum sesuai dengan yang diharapkan.

Tujuan penelitian ini untuk menemukan pokok permasalahan tentang kinerja dosen, dengan rumusan: (1) apakah terdapat pengaruh langsung efektivitas manajerial terhada kinerja?, (2) apakah terdapat pengaruh langsung self-efficacy terhadap kinerja?, (3) apakah terdapat pengaruh langsung stress kerja terhadap kinerja?, (4) apakah terdapat pengaruh langsung motivasi terhadap kinerja?, (5) apakah terdapat pengaruh langsung efektivitas manejerial terhadap motivasi kerja?, (6) apakah terdapat pengaruh langsung self-efficacy terhadap motivasi kerja?, (7) apakah terdapat pengaruh langsung stres kerja terhadap motivasi kerja?, (8) apakah terdapat pengaruh langsung efektivitas manajerial terhadap stes kerja?, dan (9) apakah terdapat pengaruh langsung self-efficacy terhadap stes kerja?. 


\section{KAJIAN TEORI}

Kinerja. Kinerja seseorang terkait dengan prosedur, mekanisme dan perilaku seseorang dalam melaksanakan suatu pekerjaan sesuai dengan bidang tugas yang diberikan dalam rangka mencapai tujuan organisasi. kinerja oleh (Colquitt, Lepine and Wesson,2013) "Job performance is formally defined as the value of the set employee behaviors that contribute, either positively or negatively, to organization goal accomplishment". Dari pernyataan tersebut dapat dinyatakan bahwa keberhasilan seseorang dalam bekerja dapat dilihat dari hasil perilaku yang mengandung nilai kerja tertentu yang dapat memberikan masukan positif dan negatif bagi organisasi dimana seseorang bekerja.

Menurut (Robbins, 2001) kinerja sebagai fungsi interaksi antara Kemampuan atau ability (A), motivasi atau motivation (M),dan kesempatan atau opportunity (O), yaitu kinerja $(\mathrm{P})=\mathrm{f}(\mathrm{AxMxO})$. Artinya: kinerja merupakan fungsi dari kemampuan, motivasi, dan kesempatan. Dengan demikian kinerja ditentukan oleh faktor-faktor kemampuan, motivasi, dan peluang. (Mathis,2011) menjelaskan ada tiga faktor yang mempengaruhi kinerja yaitu: (1) kemampuan individual untuk melakukan pekerjaan tersebut (Ability-A), (2) tingkat usaha yang dicurahkan (Effort-E), dan (3) dukungan organisasi (Support-S). Hubungan ketiga faktor ini diakui secara luas dalam literatur manajemen sebagai formula di bawah ini:

$$
\begin{aligned}
& \begin{array}{l}
\text { Kinerja (Performance }-\mathrm{P})=\text { Kemampuan (Ability-A) x Usaha } \\
(\text { Effort- E) } \mathrm{x} \\
\multicolumn{1}{c}{\text { Dukungan (Support-S) }}
\end{array}
\end{aligned}
$$

Tiga faktor utama yang mempengaruhi bagaimana kinerja individual (termasuk kuantitas dan kualitas) yaitu usaha yang dicurahkan mencakup (motivasi, etika kerja, kehadiran, rancangan tugas), kemampuan Individual mencakup (bakat, minat dan faktor kepribadian) dan dukungan Orgaanisasi:

(pelatihan dan pengembangan, peralatan dan teknologi dan standar kerja). Kinerja individual ditingkatkan sampai kepada tingkat ketiga komponen tersebut ada dalam diri karyawan, tetapi kinerja berkurang bila salah satu faktor ini dikurangi atau tidak.

Kinerja dapat dinilai dari delapan komponen yang terkait dengan penyelesaian suatu tugas. Komponen tersebut adalah: kemampuan menjalankan tugas pokok, kemampuan menjalankan di luar tugas pokok, kemampuan berkomunikasi secara tertulis dan lisan, kemauan berusaha, kedisiplinan, dukungan terhadap kinerja teman dan kelompok, kemampuan supervisi atau memimpin, dan kemampuan manajemen atau administrasi. (Campbell, 1998). Untuk mengukur kriteria penilaian kinerja, (Brown and Lent ,2005) mengungkapkan, terdapat enam kriteria yang dapat digunakan, yaitu:

(1) Quality. The degree to which the process or result of carrying out an activity approaches perfection, in term of either comforming to same ideal way of performing the activity ou fulfiling the ac-tivity's intended purpose, (2). Quantity. The amount produced, expresed in such term as dollar value, number of units, or completed activity cycles, (3). Timeliness. The degree to which an activity is comleted, or a result produced, at the earliest time desiable from the standpoint of both coordinating with the outputs of other and maximizing the time available for other activities, (4). Cost effectiveness. The degree to which the use of the 
organization's resources (e.g., human monetary, technological,material) is maximized in the sense of getting the highest gain or reduction in loss from each unit or instance of use resource, (5). Need for supervision. The degree to which a performer can carry out a job fuction without either having to requet supervisory assistance or requiring supervisory intervention to prevent an adverse outcome, (6). Interpersonal impact. The degree to which a performer promotes feelings of self esteem, goodwill, and cooperation among coworkers and subordinates.

Ada empat langkah sebagai cara untuk mencapai kinerja yang diinginkan yaitu: (1) objective setting, penentuan tujuan oleh pimpinan atau karyawan pada tingkat yang tepat dari kinerja dalam konteks tujuan secara keseluruhan unit-unit sumber daya, (2) action planning, menyusun perencanaan, tentang cara untuk mencapai tujuan tersebut, (3) periodic reviews, menilai keberhasilan yang telah dihasilkan secara periodik, dan (4) annual evaluation, melakukan evaluasi setiap tahunan untuk menilai hasil yang telah dicapai. (John W. Newstrom, Keith Davis, 2002)

Efektivitas Manajerial. Efektivitas manajerial dipahami sebagai kemampuan manajer dalam melaksanakan tugas dan fungsinyanya dengan benar, dengan memilih sasaran yang tepat yang dilakukan secara optimal dalam rangka mencapai tujuan organisasi yang telah ditetapkan. Efektivitas manajerial, menurut (J.Mullins, 2005) dikemukakan empat hal yang bersifat khusus dan satu bersifat umum, adapun yang dimaksud, yaitu:

(1) the manager work, (2) the manager himself/herself, (3) the manager relationships with other people, (4) the manager as part of the organization, and (5) creterion of general effectiveness allocation of resources, achieving purpose, goal attainment, planning, organizing,coordinating, controlling.

Implikasinya, empat kriteria terdahulu yang berkaitan dengan kehidupan manajer yaitu (1) pekerjaan manajer, yang terdiri atas pengambilan keputusan, penyelesaian masalah, melakukan inovasi, manajemen waktu dan manajemen informasi, (2) pribadi manajer dapat berupa, motivasi, persepsi peran dan sebagainya, (3) hubungan manajer dengan orang lain seperti dengan bawahan, atasan, klien, menangani konflik dan kepemimpinan, dan (4) manajer sebagai bagian dari organisasi yaitu menjaga organisasi agar selalu kondusif, kontrol tekhnik dan keuangan, (5) sedangkan kategori yang terakhir yang merupakan kriteria umum efektivitas mencakup alokasi sumberdaya, usaha-usaha untuk mencapai tujuan serta hal lain yaitu perencanaan, pengorganisasian, koordinasi dan pengawasan.

Menurut Stephen P. Robbins dan David A. De Cendo, (2009) mengemukakan empat aktifitas yang dilakukan manager yang melakukan pekerjaan terbaik. Anda akan cenderung untuk hal yang para manajer yang paling efektif dalam pekerjaan mereka juga akan menjadi orang-orang yang dipromosikan tercepat:

(1) traditional management: decision making, planning, and controlling, (2) communication : exchanging routine information and processing paperwork, (3) human resource management: motivating, disciplining, managing conflict, staffing and training, (4) networking: socializing, politicking, and interacting with outsiders.

Dijelaskan bahwa manager yang efektif melakukan aktifitas manajer dalam, (1) manajemen tradisional: pembuatan keputusan, perencanaan, dan pengendalian (19\%), (2) komunikasi: bertukar informasi rutin dan pengolahan dokumen (44\%), (3) manajemen 
sumber daya manusia: memotivasi, mendisiplinkan, mengelola konflik, personalia dan pelatihan (26\%), dan (4) jaringan: bersosialisasi, berpolitik, dan berinteraksi dengan pihak luar (11\%). Implementasi fungsi dan peran manajer dilakukan melalui penerapan fungsifungsi manajemen. (Koontz and O'Donnell,1995) manyatakan "The function of the manager tend to be universal and common to all organized human activity" Sedangkan (Stephen P. Robbins, 2012) menyatakan "Management functios, to the basic four: Planning, organizing, leading and controlling”

\begin{tabular}{llll}
\hline Planning & Oranizing & Leading & Controling \\
Setting goal, & Determining & Motivating, & Monitoring \\
establishing & what needs to be & leading, and any & activities to \\
strategies,and deve & done, how it & other achieving \\
organization \\
stated purposes
\end{tabular}

Gambar 1 Four Function of Management

Sumber: Stephen P. Robbins. Management Eleventh Edition h.37

Dalam institusi Perguruan Tinggi, didalamnya terdapat orang-orang (Dosen dan pegawai administrasi) yang harus bekerja sama, bersinergi dalam melaksanakan tugas, maka pelaksanaan fungsi manajerial menjadi penting terutama dalam membina kebersamaan sekaligus dapat menyatukan dan memberdayakan potensi-potensi semua anggota sehingga menjadi kekuatan untuk meraih keberhasilan. Kaprodi sebagai manajer diharapkan mampu melakukan tugasnya dalam memacu dan meningkatkan semangat dan motivasi kerja dosen sebagai salah satu kekuatan dalam institusi agar bekerja secara optimal sesuai kewenangan yang dimiliki. Efektivitas manajerial akan terwujud jika kegiatan yang menjadi sasaran jelas dan terukur sehingga dapat dirumuskan target-target yang mungkin dapat dicapai. Oleh karena itu kaprodi harus mengetahui secara jelas pekerjaan-pekerjaan serta target yang harus dicapai kemudian dapat menentukan proses kegiatan secara tepat.

Keyakinan- Diri (Self-Efficacy). Untuk membantu seseorang berjuang dalam mencapai satu tujuan yang diinginkan diperlukan self-efficacy, dengan keyakinan diri yang kuat akan membuat mereka melakukan pekerjaan dengan usaha yang maksimal dan bertahan terutama pada tugas yang menantang, maka harus secara sistematis mengembangkan self efficacy yang tinggi. Self-efficacy dikemukakan oleh (Ivancevich et.al, 2011) self-efficacy relates to personal beliefs regarding competencies and abilities. Specifically, it refers to one's belief in one's ability to succesfully complete a task". Efikasi diri berhubungan dengan keyakinan diri atas kompetensi dan kemampuan yang dimiliki. Secara spesifik, efikasi diri merujuk kepada keyakinan individu pada kemampuannya untuk berhasil menyelesaikan tugas

Luthans mengemukakan bahwa self-efficacy dapat menghasilkan: (1) the decision to perform the specific task in this context, keputusan untuk menampilkan tugas tertentu dalam dalam kontek tertentu, (2) the amount of effort that will be expended to accomplish the task, sebuah usaha yang dilakukan untuk menyelesaikan tugas, (3) the level of persistence that will be forthcoming despite problems, disconfirming evidence, and 
adversity, tingkat daya tahan yang muncul tidak sesuai dengan bukti dan kesulitan yang dihadapi.

Orang yang mempunyai self-efficacy tinggi biasanya melakukan pekerjaan dengan lebih baik dalam berbagai tugas, begitupun sebaliknya orang yang mempunyai self-efficacy rendah akan melakukan pekerjaannya dengan buruk. Self-efficacy tidak hanya menyangkut kekuatan atau ditentukan oleh usaha yang keras tetapi ditentukan oleh pengalaman yang berhasil. Dalam self-efficacy terdapat empat prinsip yaitu: (1) self-efficacy dapat meningkatkan prestasi pribadi, (2) self-efficacy dapat meningkatkan atau menurunkan kinerja, jika kita melihat orang lain sama dengan keberhasilan atau kegagalan dari kita pada suatu tugas tertentu, (3) kita dapat dubujuk bahwa kita mampu mengatasi atau situasi yang sulit, tetapi hal ini akan merusak jika gagal di dalam situasi tersebut, dan (4) selfefficacy memiliki hubungan dengan tekanan emosional. (Robert C Beck,1990)

Berkaitan dengan kinerja dan prilaku organisasi serta manajemen sumber daya manusia, setiap sumber self-efficacy bersifat lunak dan dapat diubah, karena self-efficacy bukan merupakan karekteristik, dalam arti self-efficacy dapat ditingkatkan melalui pelatihan atau pengembangan yang tertuju pada sumber-sumber sebagai berikut: (1) pengalaman penguasaan dan pencapaian kinerja, (2) pengalaman pribadi dan pemodelan, (3) persuasi sosial, dan (4) peningkatan fisik dan emosional atau psikologis. (Luthans) Demikian juga kouzer dan posner mendukung pendapat diatas bahwa untuk meningkatkan self-efficacy ada empat yaitu: (1) penguasaan, (2) pengambilan model, (3) dukungan, (4) penafsirkan kembali stres. Pengambilan model atau penguasaan adalah belajar melaksanakan tugas dengan baik, dukungan adalah mendengarkan dari orang yang memberi semangat dan dorongan untuk bekerja sebaik mungkin, menafsirkan kembali stress adalah membaca isyarat stres sehingga dalam melaksanakan tugas yang baik dan menentukan cara-cara memodifikasi keyakinan dengan kemampuan ketika merasakan isyarat stres.

Menurut (Badura,1997) semakin kuat persepsi self-efficacy semakin giat dan tekun usaha-usahanya. Ketika mengahadapi kesulitan, individu yang mempunyai keraguan diri yang besar tentang kemampuannya akan mengurangi usaha-usaha atau menyerah sama sekali. Sedangkan mereka yang mempunyai perasaan efficacy yang kuat menggunakan usaha yang lebih besar untuk mengatasi tantangan.

Stress Kerja. Stres adalah masalah yang posisinya sangat penting dalam kaitannya dengan kinerja karyawan. Selain dipengaruhi oleh faktor-faktor yang bersumber dari luar organisasi, stres juga banyak dipengaruhi oleh faktor-faktor yang berasal dari dalam organisasi. Beberapa ahli akan membahas tentang stres dilingkungan kerja. Sedangkan pendapat (John W.Slocum,2009) tentang stress kerja dinyatakan bahwa:

"Job stress is a common and costly problem in the workplace, leaving few workers untouched. Stress is the excitement, feeling of anxiety, and/or physical tension that accurs when the demands placed on an individual aare though to exceed the person's ability to cope."

Davis dan Newstrom stres kerja disebabkan: (1) adanya tugas yang terlalu banyak. (2) supervisor yang kurang pandai, dan (3) terbatasnya waktu dalam mengerjakan pekerjaan, (4) kurang mendapat tanggungjawab yang memadai.(5) ambiguitas peran,(6) perbedaan nilai dengan perusahaan, (7) frustrasi. (8) perubahan tipe pekerjaan, dan (9) konflik peran. Hampir semua orang pernah mengalami kelebihan beban kerja dan tingkat insiden tersebut semakin meningkat. Kelebihan beban kerja terdiri dari dua jenis: kualitatif 
atau kuantitatif, kelebihan beban kualitatif muncul ketika orang merasa kurang memiliki kemampuan yang diperlukan untuk menyelesaikan pekerjaan yang diberikan kepadanya atau bahwa standar kinerja yang telah ditetapkan terlalu tinggi sehingga seseorang tidak memiliki kemampuan untuk menyelesaikannya, kelebihan beban kuantitaif, dilain pihak dihasilkan dari terlalu banyaknya hal yang harus dilakukan atau tidak terdapat cukup waktu untuk menyelesaikan suatu pekerjaan.

Pengaruh rangkaian kesatuan kekurangan beban kerja dan beban berlebih terhadap tingkat stress optimal yang berpengaruh kinerja seseorang.

\section{STREES}

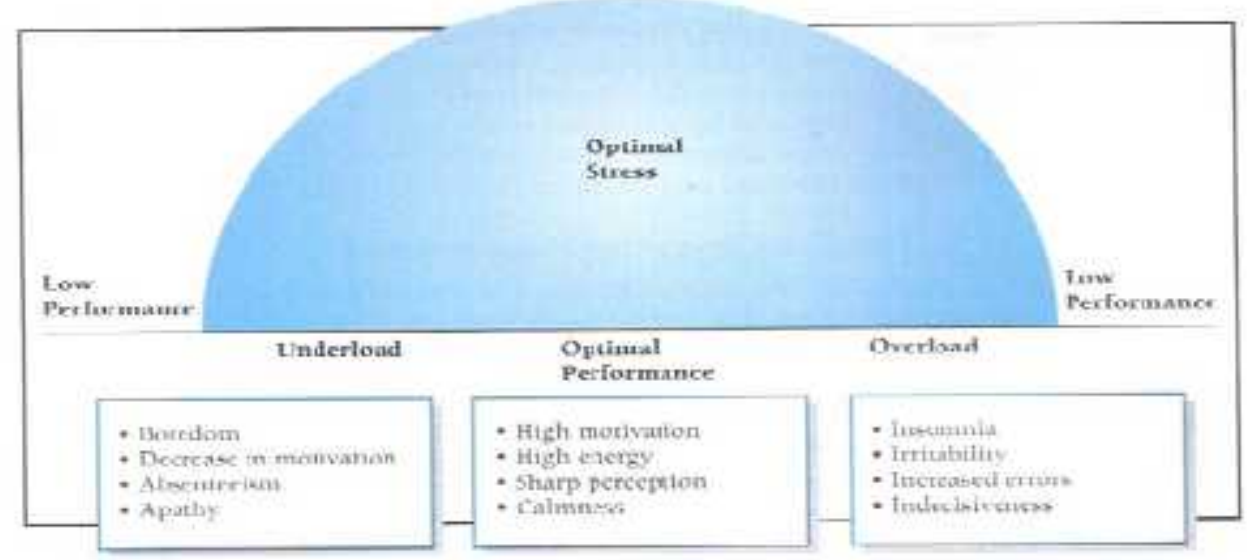

Gambar. 2. The Underload-Overload Continum

Sumber: John M. Ivancevich. Organizational Behavior and Management (New York. McGraw Hill Irwin, 2011. H. 247).

Untuk mengelola stress, (Stephen P. Robbins) mengemukakan bahwa mengelola stress dapat ditinjau dari dua hal, yaitu pendekatan individu dan pendekatan organisasi:

Contrast the individual and organizational approaches to managing stress. Individual approaches, an employee can take personal responsibility for reducing stress level. Individual strategies that have proven effective include time management techniques, increased physical exercise, relaxation training, and expended social support network. Organisational approach,several factor that cause stressparticulary task and roledemand-are controlled by management and thus can be modified or changed. Strategies to consider include improved personnel selection and job placement, training, goal setting, redesign of job, increased employee involvement, improved organizational communication, employee sabbaticals, and corporate wellness programs.

Perbedaan pendekatan individu dan organisasi dalam mengelola stress, pendekatan individu, karyawan dapat memikul tanggungjawab pribadi untuk mengurangi tingkat stresnya. Strategi individu yang telah terbukti efektif mencakup pelaksanaan teknik-teknik manajemen waktu, meningkatkan latihan fisik, pelatihan relaksasi, dan memperluas jaringan dukungan sosal. Pendekatan organisasional, beberapa faktor yang menyebabkan stres-terutama tuntutan tugas dan peran-dikendalikan oleh manajemen, dengan demikian faktor-faktor ini dapat dimodifikasi atau diubah. Strategi yang mungkin dipertimbangkan 
oleh manajemen antara lain perbaikan seleksi personil dan penempatan kerja, penetapan sasaran yang realistis, perancangan ulang pekerjaan peningkatan keterlibatan karyawan, perbaikan komunikasi organisasi dan penegakan program kesejahteraan korporasi.

Motivasi Kerja. Motivasi kerja menurut (Craig C. Pinder,2008) menyatakan ” Work motivation is a set of energetic forces that originate both within as well beyond an individual's being, to intiate work-related behavior, and to determine its form, direction, intensity, and duration". Motivasi kerja adalah kekuatan energi yang berasal dari dalam maupun dari luar diri individu, untuk memulai pekerjaan yang berhubungan dengan prilaku, menentukan bentuk, arah, intensitas, dan durasi. Selanjutnya (Schermerhorn, Hunt \& Osborn,2010) berpendapat bahwa "motivation to work is term used in organizational behavior to describe the forces within an individual that account for the level, direction and persistence of effort expended at work".

Teori motivasi di hubungkan dengan hirarki kebutuhan menurut Abraham Maslow berdasarkan tingkatan yang terdiri dari psychological needs (kebutuhan fisik), safety needs (kebutuhan rasa aman), affection needs (kebutuhan untuk di cintai dan di terima oleh orang lain), esteem needs (penghargaan/pengakuan), dan selfactualization needs (kebutuhanakan aktualisasi diri). Hirarki kebutuhan yang dikembangkan oleh Maslow yang didasari dari teori kebutuhan manusia dalam hubungan dengan pekerjaan yang mengambarkan kebutuhan-kebutuhan dasar yang dibutuhkan dalam dunia kerja dalam motivasi kerja adalah sebagai berikut:

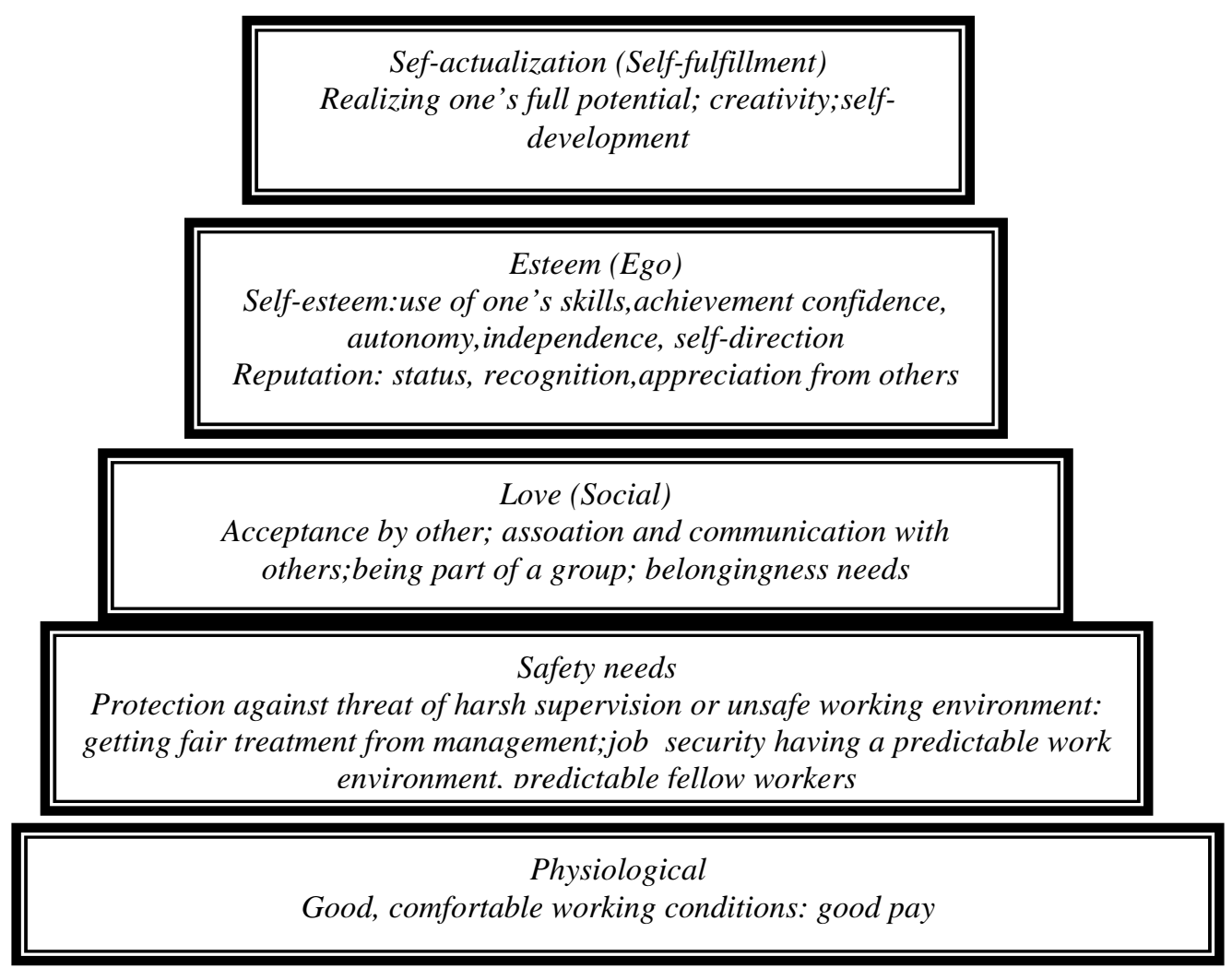

Gambar 3. Maslow's Hierarchy of Needs Requiring Fulfillment in a Work Environment Sumber: A.B. (Rami) Shani/James B. Lau; Organizational Behavior an Experiental Approach. 2005. h. 235 
Indikator untuk mengetahui motivasi seseorang dalam suatu kegiatan (1).durasi kegiatan (berapa lama kemampuan penggunaan waktu untuk melakukan kegiatan), frekuensi kegiatan (berapa sering kegiatan dilakukan dalam periode waktu tertentu). (2) persistensinya (ketetapan dan kelekatannya) pada tujuan kegiatan, (3) ketabahan, keuletan dan kesulitan untuk mencapai tujuan, (4) pengabdian dan pengorbanan untuk mencapai tujuan, (5) tingkat aspirasi (maksud, rencana, cita-cita, sasaran atau target), (6) tingkat kualifikasi prestasi atau produk yang dicapai dari kegiatannya, (7) arah sikapnya terhadap sasaran kegiatan.

Beberapa cara pendekatan untuk dapat memotivasi diri seseorang dalam bekerja, $\mathrm{M}$. Tamar mengutip pendapat Schunk menyatakan: (1) pendekatan behavioral menjelaskan motivasi melalui konsep reward (ganjaran) dan insentif). (2) pendekatan humanistic memberikan penekanan pada sumber-sumber yang berasal dari dalam diri seseorang (intrinsic motivation), (3) pendekatan cognitive memandang motivasi sebagai sesuatu yang intrinsic sifatnya. dan (4) pendekatan social learning menjabarkan motivasi melalui dua pendekatan sebelumnya. Mereka menjembatani perhatian para ahli tingkah laku (behaviouristic) dan para ahli kognitif (cognitive), yaitu perhatian para ahli tingkah laku terhadap efek atau hasil tingkah laku, dan perhatian para ahli kognitif terhadap dampak dan kepercayaan serta harapan seseorang.

\section{Hipotesis}

1. Terdapat pengaruh langsung koefisien jalur pada populasi efektivitas manajerial terhadap kinerja

2. Terdapat pengaruh langsung koefisien jalur pada populasi self-efficacy terhadap kinerja

3. Terdapat pengaruh langsung koefisien jalur pada populasi stres kerja terhadap kinerja

4. Terdapat pengaruh langsung koefisien jalur pada populasi motivasi Kerja terhadap kinerja

5. Terdapat pengaruh langsung koefisien jalur pada populasi efektivitas manajerial terhadap motivasi kerja

6. Terdapat pengaruh langsung koefisien jalur pada populasi self-efficacy terhadap motivasi kerja

7. Terdapat pengaruh langsung koefisien jalur pada populasi stres kerja terhadap motivasi kerja

8. Terdapat pengaruh langsung koefisien jalur pada populasi efektivitas manajerial terhadap stres kerja

9. Terdapat pengaruh langsung koefisien jalur pada populasi self-efficacy terhadap stres kerja

Kerangka teori. Kerangka teori yang melandasi konstelasi disertasi ini berdasarkan kerangka konsep yang dikembangkan oleh Qolquit (2013) seperti pada Gambar 4. 


\section{Organizational}

Mechanisms

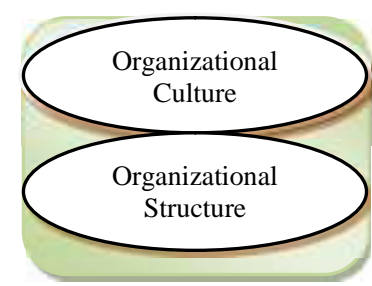

\section{Individual}

Mechanisms
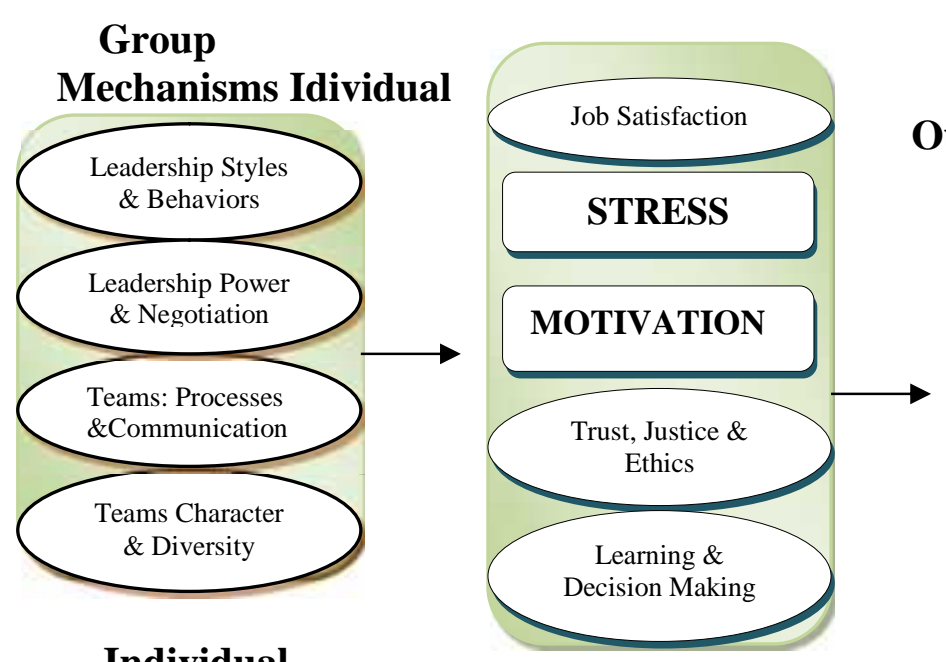

Outcomes

Individual

Characteristics

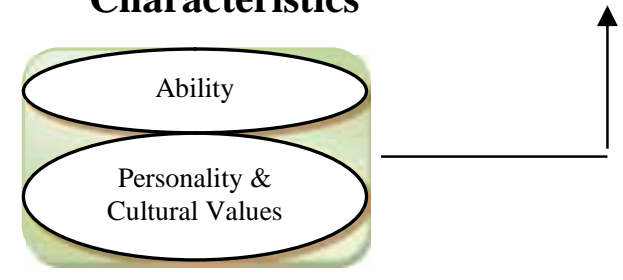

Gambar 4. Integrative Model of Organizational Behavior

Sumber: Colquitt,Lepine, Wesson,"Organizational Behavior. Mc Graw-

Hill companies, Inc .2013. h.8

Konstelasi hubungan antar variabel-variabel penelitian dapat dilihat pada gambar sebagai berikut: 


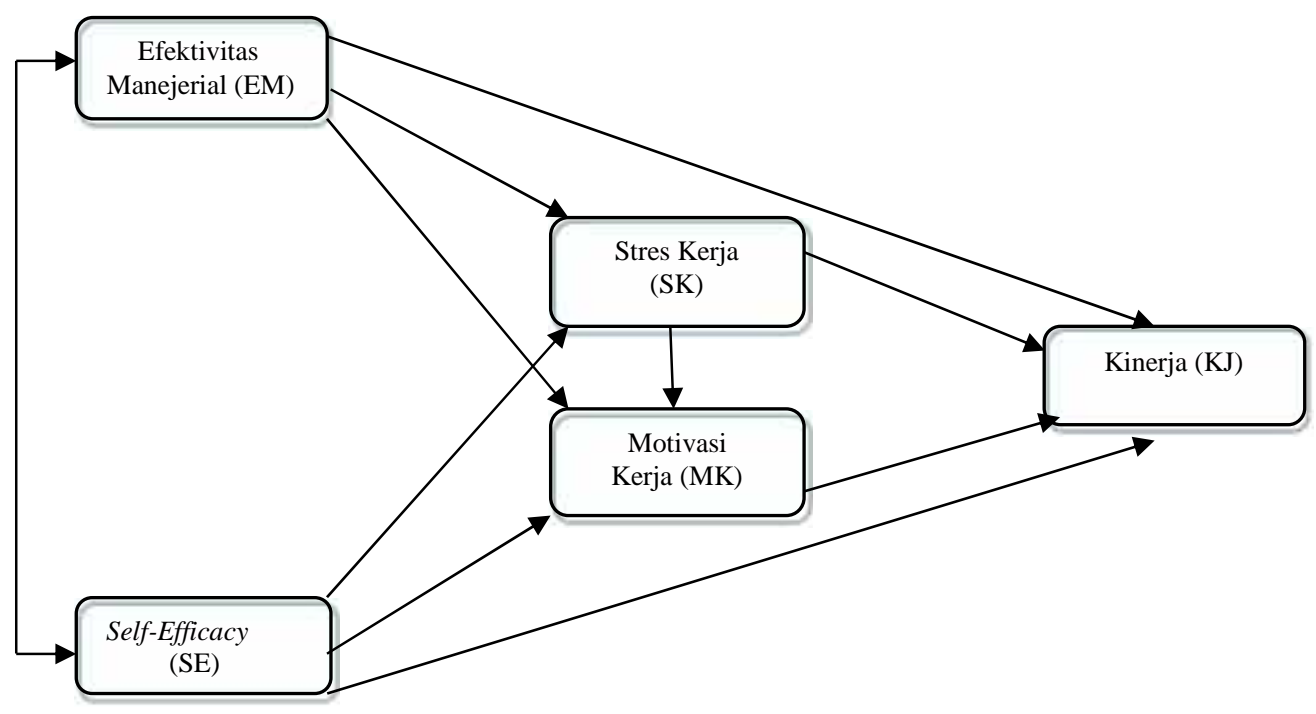

Gambar 5. Model Konstelasi awal penelitian hubungan antar variabel.

\section{METODE}

Penelitian ini dilakukan menggunakan pendekatan kuantitatif dengan, metode penelitian yang digunakan adalah survei dengan pendekatan kausal, hasil survey dianalisis menggunakan statistik multivariat dengan teknik analisis jalur path analysis. Populasi penelitian ini adalah seluruh dosen program studi kebidanan di Provinsi Lampung yang berjumlah 167 dosen, berdasarkan proporsional random sampling didapat sampel sebanyak 118 dosen yang dijadikan responden. Dalam penelitian ini menggunakan 5 instrumen yaitu: kinerja, efektivitas manajerial, self-efficacy, stress kerja dan motivasi kerja. Sebelum dilakukan analisis jalur, dilakukan beberapa syarat pengujian yang harus dipenuhi yaitu: uji normalitas data, uji linearitas dan uji signifikansi regresi.

\section{HASIL DAN PEMBAHASAN}

Tabel 1. Rangkuman Data Kinerja, Efektivitas Manajerial, Self-Efficacy,

\begin{tabular}{|c|c|c|c|c|c|c|}
\hline \multirow[b]{2}{*}{ Variabel } & \multicolumn{6}{|c|}{ Stress Kerja, dan Motivasi Kerja } \\
\hline & $\begin{array}{l}\text { Jumlah } \\
\text { Responden }\end{array}$ & Mean & Median & Modus & $\begin{array}{c}\text { Simpangan } \\
\text { Baku }\end{array}$ & Varians \\
\hline KJ & 118 & 92,00 & 90 & 85 & 10,03 & 100,55 \\
\hline EM & 118 & 84,98 & 85 & 87 & 10,03 & 100,63 \\
\hline SE & 118 & 83,88 & 84 & 87 & 10,13 & 102,60 \\
\hline SK & 118 & 86,86 & 87 & 90 & 10,08 & 101,59 \\
\hline MK & 118 & 88,47 & 89 & 103 & 10,00 & 99,96 \\
\hline
\end{tabular}

Sebelum dilakukan analisis jalur dilaksanakan juga apa yang dipersyaratkan yaitu: uji normalitas data, uji linearitas dan signifikansi regresi, hasil analisis jalur sebagai berikut. 
Koefisien jalur sub struktur 1. Hasil analisis jalur pengaruh efektivitas manejerial (EM), Self-efficacy (SE), stres kerja (SK) dan motivasi kerja (MK) terhadap kinerja (KJ) diperoleh koefisien jalur pada Tabel 2.

Tabel 2. Hasil Koefisien Jalur KJ terhadap EM,SE,SK,MK

\begin{tabular}{|c|c|c|c|c|c|c|c|c|c|}
\hline \multicolumn{10}{|c|}{ Coefficients $^{\mathrm{a}}$} \\
\hline \multirow{2}{*}{\multicolumn{2}{|c|}{ Model }} & \multicolumn{2}{|c|}{$\begin{array}{l}\text { Unstandardized } \\
\text { Coefficients }\end{array}$} & \multirow{2}{*}{$\begin{array}{c}\begin{array}{c}\text { Standardized } \\
\text { Coefficients }\end{array} \\
\text { Beta } \\
\end{array}$} & \multirow[b]{2}{*}{$\mathrm{T}$} & \multirow[b]{2}{*}{ Sig. } & \multicolumn{3}{|c|}{ Correlations } \\
\hline & & B & $\begin{array}{l}\text { Std. } \\
\text { Error }\end{array}$ & & & & $\begin{array}{l}\text { Zero- } \\
\text { order }\end{array}$ & Partial & Part \\
\hline \multirow[t]{5}{*}{1} & $\begin{array}{l}\text { (Consta } \\
\text { nt) }\end{array}$ & 58.375 & 13.705 & & 4.259 & .000 & & & \\
\hline & EM & .208 & .086 & .208 & 2.410 & .018 & .771 & .221 & .116 \\
\hline & SE & .249 & .080 & .251 & 3.117 & .002 & .769 & .281 & .150 \\
\hline & SK & -.281 & .080 & -.282 & -3.524 & .001 & -.776 & -.315 & -.169 \\
\hline & MK & .221 & .082 & .220 & 2.705 & .008 & .760 & .247 & .130 \\
\hline
\end{tabular}

a. Dependent Variable: KJ

Koefisien jalur sub struktur 2. Hasil analisis jalur pengaruh efektivitas manejerial (EM) dan Self-efficacy (SE), dan Stress Kerja (SK) terhadap Motivasi kerja (MK) diperoleh koefisien jalur pada Tabel 3.

Tabel 3. Hasil Koefisien Jalur MK terhadap EM,SE,SK

\section{Coefficients $^{\mathrm{a}}$}

\begin{tabular}{|c|c|c|c|c|c|c|c|c|c|}
\hline & & \multicolumn{2}{|c|}{$\begin{array}{l}\text { Unstandardized } \\
\text { Coefficients }\end{array}$} & \multirow{2}{*}{$\begin{array}{c}\begin{array}{c}\text { Standardized } \\
\text { Coefficients }\end{array} \\
\text { Beta } \\
\end{array}$} & & \multirow[b]{2}{*}{ Sig. } & \multicolumn{3}{|c|}{ Correlations } \\
\hline \multicolumn{2}{|c|}{ Model } & $\mathrm{B}$ & $\begin{array}{l}\text { Std. } \\
\text { Error }\end{array}$ & & & & $\begin{array}{l}\text { Zero- } \\
\text { order }\end{array}$ & Partial & Part \\
\hline \multirow[t]{4}{*}{1} & (Constant) & 50.586 & 14.999 & & 3.373 & .001 & & & \\
\hline & $\mathrm{EM}$ & .382 & .092 & .383 & 4.145 & .000 & .757 & .362 & .229 \\
\hline & SE & .285 & .088 & .289 & 3.253 & .002 & .727 & .291 & .180 \\
\hline & SK & -.213 & .089 & -.214 & -2.380 & .019 & -.710 & -.218 & -.132 \\
\hline
\end{tabular}

a.Dependent Variable: MK

Koefisien jalur sub struktur 3. Hasil analisis jalur pengaruh efektivitas manejerial (EM) dan Self-efficacy (SE) terhadap Stress Kerja (SK) diperoleh koefisien jalur pada tabel berikut. 
Tabel 4. Hasil Koefisien Jalur SK terhadap EM,SE

\begin{tabular}{|c|c|c|c|c|c|c|c|c|c|}
\hline \multicolumn{10}{|c|}{ Coefficients $^{\mathrm{a}}$} \\
\hline & & \multicolumn{2}{|c|}{$\begin{array}{l}\text { Unstandardized } \\
\text { Coefficients }\end{array}$} & \multirow{2}{*}{$\begin{array}{c}\text { Standardized } \\
\text { Coefficients } \\
\text { Beta }\end{array}$} & \multirow[b]{2}{*}{$\mathrm{T}$} & \multirow[b]{2}{*}{ Sig. } & \multicolumn{3}{|c|}{ Correlations } \\
\hline \multicolumn{2}{|c|}{ Model } & $\mathrm{B}$ & $\begin{array}{l}\text { Std. } \\
\text { Error }\end{array}$ & & & & $\begin{array}{l}\text { Zero- } \\
\text { order }\end{array}$ & Partial & Part \\
\hline \multirow[t]{3}{*}{1} & (Constant) & 158.356 & 5.214 & & 30.370 & .000 & & & \\
\hline & EM & -.475 & .085 & -.472 & -5.557 & .000 & -.749 & -.460 & -.318 \\
\hline & SE & -.371 & .085 & -.373 & -4.390 & .000 & -.723 & -.379 & -.251 \\
\hline
\end{tabular}

a.Dependent Variable: SK

Berdasarkan pengujian analisis jalur tersebut di atas, maka dapat dijelaskan pengujian hipotesis sebagai berikut:

Pertama: hasil analisis jalur pengaruh efektivitas manejerial (EM) terhadap kinerja dosen $(\mathrm{KJ})$ diperoleh koefisien jalur py $1=0,208$ thitung $_{1}$ sebesar $=2,410$, sedangkan untuk nilai $t_{\text {tabel }}$ dengan $\mathrm{dk}=113$ dan pada taraf signifikansi $\alpha(0,05)=1,9812$, karena nilai $\left|\mathrm{t}_{\text {hitung }}\right|>\mathrm{t}_{\text {tabel }}$ maka $\mathrm{H}_{0}$ ditolak; disimpulkan bahwa efektifitas manejerial berpengaruh langsung positif terhadap kinerja dosen kebidanan di Provinsi Lampung. Kedua: hasil analisis jalur pengaruh self-efficacy (SE) terhadap kinerja dosen $(\mathrm{KJ})$ diperoleh koefisien jalur $\mathrm{py}_{2}=$ 0,251 thitung sebesar $=3,117$, sedangkan untuk nilai $t_{\text {tabel }}$ dengan $\mathrm{dk}=113$ dan pada taraf signifikansi $\alpha(0,05)=0,9812$, karena nilai $\left|t_{\text {hitung }}\right|>t_{\text {tabel }}$ maka $\mathrm{H}_{0}$ ditolak; disimpulkan bahwa self- efficacy berpengaruh langsung positif terhadap kinerja dosen kebidanan di Provinsi Lampung. Ketiga: hasil analisis jalur pengaruh stres kerja (SK) terhadap kinerja dosen $(\mathrm{KJ})$ diperoleh koefisien jalur $\mathrm{py}_{3}=-0,282 \mathrm{t}_{\text {hitung }}$ sebesar $=-3,524$, sedangkan untuk nilai $t_{\text {tabel }}$ dengan $\mathrm{dk}=113$ dan pada taraf signifikansi $\alpha(0,05)=1,9812$, karena nilai $\left|t_{\text {hitung }}\right|$ $>$ tabel maka $\mathrm{H}_{0}$ ditolak; disimpulkan bahwa stress kerja berpengaruh langsung negatif terhadap kinerja dosen kebidanan di Provinsi Lampung. Keempat: hasil analisis jalur pengaruh motivasi kerja $(\mathrm{MK})$ terhadap kinerja dosen $(\mathrm{KJ})$ diperoleh koefisien jalur py $4=$ $0,220 t_{\text {hitung }}$ sebesar $=2,705$. Sedangkan untuk nilai $t_{\text {tabel }}$ dengan $\mathrm{dk}=113$ dan pada taraf signifikansi $\alpha(0,05)=1,9812$, karena nilai $\left|t_{\text {hitung }}\right|>t_{\text {tabel }}$ maka $\mathrm{H}_{0}$ ditolak; disimpulkan bahwa motivasi kerja berpengaruh langsung positif terhadap kinerja dosen kebidanan di Provinsi Lampung. Kelima: hasil analisis jalur pengaruh efektivitas manejerial (EM) terhadap motivasi kerja (MK) diperoleh koefisien jalur $\mathrm{p}_{41}=0,383$ thitung sebesar $=4,145$, sedangkan untuk nilai $t_{\text {tabel }}$ dengan $\mathrm{dk}=114$ dan pada taraf signifikansi $\alpha(0,05)=1,9810$, karena nilai $\left|t_{\text {hitung }}\right|>t_{\text {tabel }}$ maka $\mathrm{H}_{0}$ ditolak; disimpulkan bahwa efektifitas manejerial berpengaruh langsung positif terhadap motivasi kerja dosen kebidanan di Provinsi Lampung. Keenam: hasil analisis jalur pengaruh self-efficacy (SE) terhadap motivasi kerja (MK) diperoleh koefisien jalur $\mathrm{p}_{42}=0,289 \mathrm{t}_{\text {hitung }}$ sebesar $=3,253$, sedangkan untuk nilai $t_{\text {tabel }}$ dengan $\mathrm{dk}=114$ dan pada taraf signifikansi $\alpha(0,05)=1,9810$, karena nilai $\left|t_{\text {hitung }}\right|$ $>\mathrm{t}_{\text {tabel }}$ maka $\mathrm{H}_{0}$ ditolak; disimpulkan bahwa self-efficacy berpengaruh langsung positif terhadap motivasi kerja dosen kebidanan di Provinsi Lampung. Ketujuh: hasil analisis jalur pengaruh stress kerja (SK) terhadap motivasi kerja (MK) diperoleh koefisien jalur $\mathrm{p}_{43}$ $=-0,214 t_{\text {hitung }}$ sebesar $=-2,380$. Sedangkan untuk nilai $t_{\text {tabel }}$ dengan $\mathrm{dk}=114$ dan pada taraf signifikansi $\alpha(0,05)=1,9810$, karena nilai $\left|t_{\text {hitung }}\right|>t_{\text {tabel }}$ maka $\mathrm{H}_{0}$ ditolak; disimpulkan bahwa stres kerja berpengaruh langsung negatif terhadap motivasi kerja dosen kebidanan 
di Provinsi Lampung. Kedelapan: hasil analisis jalur pengaruh efektivitas manejerial (EM) terhadap stress kerja (SK) diperoleh koefisien jalur $\mathrm{p}_{31}=-0,472 \mathrm{t}_{\text {hitung }}$ sebesar $=$ 5,557 , sedangkan untuk nilai tabel dengan $d k=115$ dan pada taraf signifikansi $\alpha(0,05)=$ 1,9808, karena nilai $\left|\mathrm{t}_{\text {hitung }}\right|>\mathrm{t}_{\text {tabel }}$ maka $\mathrm{H}_{0}$ ditolak; disimpulkan bahwa efektifitas manejerial berpengaruh langsung negatif terhadap stres kerja dosen kebidanan di Provinsi Lampung. Kesembilan: hasil analisis jalur pengaruh self-efficacy (SE) terhadap stress kerja (SK) diperoleh koefisien jalur $\mathrm{p}_{32}=-0,373 \mathrm{t}_{\text {hitung }}$ sebesar $=-4,390$ Sedangkan untuk nilai $t_{\text {tabel }}$ dengan $\mathrm{dk}=115$ dan pada taraf signifikansi $\alpha(0,05)=1,9808$, karena nilai $\left|t_{\text {hitung }}\right|$ $>t_{\text {tabel }}$ maka $\mathrm{H}_{0}$ ditolak; disimpulkan bahwa self-efficacy berpengaruh langsung negatif terhadap stress kerja dosen kebidanan di Provinsi Lampung.

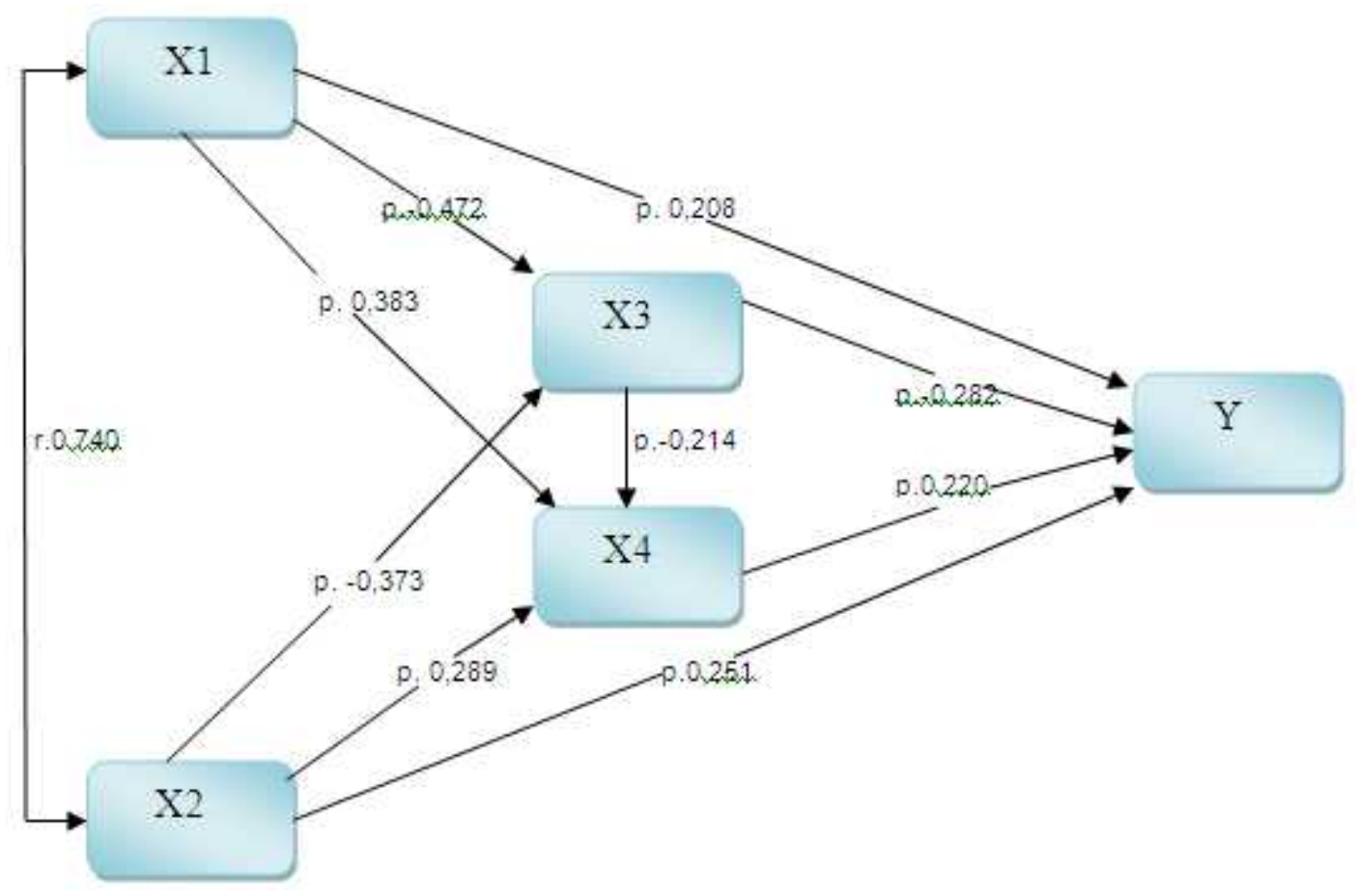

Gambar. 6. Model akhir analisis jalur

Efektivitas manajerial berpengaruh langsung positif terhadap kinerja. Efektivitas manajerial berpengaruh langsung positif terhadap kinerja dosen kebidanan di provinsi Lampung, artinya ketepatan efektivitas manejerial yang dilakukan oleh kaprodi di program studi kebidanan akan menyebabkan peningkatan kinerja yang dilakukan oleh dosen. Efektivitas manajerial dimaknai sebagai kemampuan seorang manajer dalam melaksanakan fungsi manajemen secara efektif diantaranya adalah: perencanaan, pengorganisasian, penggerakan, dan pengawasan dalam institusi yang dipimpinnya agar dapat mencapai tujuan yang diinginkan. Hal ini sejalan dengan pendapat Robbins (2012: 37) yang menyatakan fungsi manajemen "Management functios, though these have generally been condensed down to the basic four: Planning, organizing, leading and controlling" Kinerja merupakan rangkaian perilaku unjuk kerja yang ditampilkan seseorang dosen dalam pelaksanaan tugas pokoknya mencakup tri dharma perguruan tinggi, dengan indikator: nilai kerja, rancangan kerja, kuantitas kerja, kualitas kerja dalam rangka pencapaian tujuan institusi. Konsep kinerja yang sesuai dengan pernyataan diatas diungkapkan oleh Gibson (2006: 372) yang menyatakan bahwa "Job performance is 
the outcome of job relate to the oeganization such as quality, efficiency, and other criteria of effectiveness" Munculnya kinerja dosen kebidanan yang sesuai dengan metode, perilaku, prosedur dan hasil disebabkan ketepatan manajemen seorang kaprodi selaku atasan langsung dosen dalam melaksanakan/melakukan mengawasi dan menilai kinerja dosen dan dapat menerapkan fungsi manejemen diantaranya dengan usaha efektif untuk mencapai tujuan, perencanaan yang dapat terukur secara jelas, melaksanakan pengorganisasian yang efektif, dan menggerakan semua potensi dosen, serta melakukan pengawasan dalam institusi tersebut secara efektif diharapkan akan dapat meningkatnya kinerja yang dilakukan oleh dosen yang pada akhirnya akan berdampak pada peningkatan kualitas program studi kebidanan di Provinsi lampung.

Self-efficacy berpengaruh langsung positif terhadap kinerja. Self-efficacy berpengaruh langsung positif terhadap kinerja dosen kebidanan di Provinsi Lampung, artinya semakin kuat self-efficacy yang dimiliki oleh dosen akan menyebabkan semakin tepat kinerja yang akan dilakukan oleh dosen. Temuan ini sesuai oleh pendapat Badura (1998: 2) yang menyatakan bahwa: semakin kuat persepsi self efficacy semakin giat dan tekun usahausahanya. Ketika mengahadapi kesulitan, individu yang mempunyai keraguan diri yang besar tentang kemampuannya akan mengurangi usaha-usaha atau menyerah sama sekali, sedangkan mereka yang mempunyai perasaan efficacy yang kuat menggunakan usaha yang lebih besar untuk mengatasi tantangan. Dosen yang memiliki keyakinan diri yang kuat akan menyebabkan terjadinya unjuk kerja yang tepat bagi dosen, baik berhubungan dengan perilaku kerja, metode kerja, prosedur kerja maupun hasil kerja.

Stres kerja berpengaruh langsung negatif terhadap kinerja. Stres kerja berpengaruh langsung negatif terhadap kinerja dosen kebidanan di Provinsi Lampung, artinya semakin tinggi stres dosen dalam menghadapi pekerjaannya akan dapat menyebabkan ketidak tepatan kinerja yang akan dilakukan oleh dosen. Stress kerja adalah suatu kondisi ketegangan yang dirasakan karyawan dalam bekerja yang menimbulkan respon adaptif terhadap psikologis dan fisik, Pernyataan ini didukung oleh pendapat Richmond (1999: 182) mengenai stres kerja; "Work stress is defined as the harmful physical and emotional responses that occur when job requirements do not match the worker's capabilities, resources, and needs.”.

Dalam hubungannya dengan pekerjaan stres umumnya terjadi akibat faktor lingkungan, organisasi dan individu, adapun dalam konteks organisasi, stres umumnya terjadi akibat persaingan, dalam hubungannya dengan tempat kerja, stres dapat timbul pada beberapa tingkat dari mulai ketidak mampuan dalam bekerja dengan baik, kesalah pahaman atasan atau bawahan, kelebihan/kekurangan beban kerja. Menurut Colquitt (2013: 140) stres akan berpengaruh pada gangguan physiological, psychological dan behavioral. Sebagai dampak dari adanya stres kerja dosen mengalami beberapa gejala stres yang dapat mengancam dan mengganggu pelaksanaan kerja dosen dalam bidang pendidikan dan pembelajaran, penelitian dan pengabdian pada masyarakat.

Motivasi kerja berpengaruh langsung positif terhadap kinerja. Motivasi kerja berpengaruh langsung positif terhadap kinerja dosen kebidanan di Provinsi Lampung, artinya semakin kuat motivasi kerja yang timbul dalam diri dosen akan menyebabkan semakin tepat pula kinerja yang akan dilakukan oleh dosen. hal ini diperkuat oleh pendapat M. Jex (2002: 100) yang menyatakan kinerja adalah " Job performance are caused by the interaction among ability, motivation, and situational factors that may facilitate or inhibit 
performance”. Untuk meningkatkan kinerja dosen kebidanan diperlukan motivasi seseorang dalam mencapai tujuan yang diharapkan. Pernyataan ini sesuai dengan pendapat L. Daft (2001:117), yang menyatakan bahwa kinerja pekerjaan adalah pengukuran tingkat perilaku individu atau kontribusi tindakan sesorang untuk mencapai tujuan organisasi, kinerja karyawan sebagai fungsi (f) dari interaksi antara kemampuan (A) dan motivasi (M) sehingga kinerja $=\mathrm{f}(\mathrm{A} \times \mathrm{M})$. Pengaruh motivasi pada kinerja, motivasi kerja memiliki pengaruh positif yang kuat terhadap kinerja, orang yang mempunyai tingkat motivasi yang tinggi cenderung memiliki kinerja yang tinggi, begitupun sebaliknya, seseorang yang termotivasi rendah akan cendrung memiliki kinerja yang rendah pula. Maka dapat disimpulkan bahwa semakin kuat motivasi kerja yang dimiliki dosen akan menyebabkan terjadinya peningkatkan kinerja dosen, baik dari proses maupun hasil kerja.

Efektivitas manejerial berpengaruh langsung positif terhadap motivasi kerja. Efektivitas manajerial berpengaruh langsung positif terhadap motivasi kerja dosen kebidanan di Provinsi Lampung, artinya semakin tepat efektivitas manejerial yang dilakukan oleh kaprodi akan menyebabkan semakin meningkat motivasi kerja yang timbul dalam diri dosen, sebaliknya semakin tidak tepat efektivitas manejerial yang dilakukan kaprodi akan menyebabkan penurunan motivasi kerja yang ada dalam diri dosen. Penelitian ini diperkuat juga oleh pendapat Robbins dan David A. De Cendo (2002: 120) yang mengemukakan bahwa empat aktifitas yang dilakukan manager yang efektif melakukan pekerjaan terbaik, empat aktivitas tersebut:

(1) traditional managemen: decision making, planning, and controlling, (2) communication: exchanging routine information and processing paperwork, (3) human resource management: motivating, disciplining, managing conflict, staffing and training, and (4) networking; socializing, politicking, and interacting with outsiders.

Efektivitas manejerial yang yang dilakukan kaprodi dengan menjalankan fungsi manajemennya akan menyebabkan meningkatkan motivasi kerja dosen, hal dapat dilihat dari fungsi ketiga seorang manejer dalam organisasi adalah pengarahan sering juga dikatakan bahwa kepemimpinan adalah tindakan manajer mempengaruhi orang lain agar mereka mau bekerja, fungsi pengarahan bisa menyangkut motivasi, komunikasi dan kepemimpinan yang semuanya merupakan kegiatan kaprodi yang secara langsung berhadapan dengan dosen. Kaprodi sebagai manajer diharapkan mampu melakukan tugasnya dalam memacu dan meningkatkan semangat dan motivasi kerja dosen sebagai salah satu kekuatan dalam institusi agar bekerja secara optimal sesuai kewenangan yang dimiliki.

Self-efficacy berpengaruh langsung positif terhadap motivasi kerja. Self-efficcy berpengaruh langsung positif terhadap motivasi kerja dosen kebidanan di provinsi Lampung, artinya semakin kuat self-efficacy yang dimiliki oleh dosen akan menyebabkan peningkatan motivasi kerja yang timbul dalam diri dosen. Pendapat yang sejalan dengan hasil penelitian penulis bahwa keyakinan diri yang kuat sangatlah berpengaruh positif terhadap motivasi kerja dosen dikemukakan oleh Luthans (2011: 203) tentang keyakinan diri: Self-efficacy refers to an individual's convection (or confidence) about his or her abilities to mobilize the motivation, cognitif resources, and courses of action needed to successfully execute a specific task within a given context". Dinyatakan bahwa dengan self-efficacy yang kuat yang ada dalam diri seseorang akan menyebabkan menambah tingginya motivasi seseorang dalam melakukan tugas-tugas tertentu yang sulit tersebut 
dimana seseorang lebih bersemangat untuk melaksanakannya dan dapat menyelesaikannya dengan lebih baik dan pada akhirnya akan berdampak pada peningkatan kinerja dosen.

Stres kerja berpengaruh langsung negatif terhadap motivasi kerja. Stres kerja berpengaruh langsung negatif terhadap motivasi kerja dosen kebidanan di provinsi Lampung, artinya stres kerja yang terjadi pada diri dosen akan menyebabkan penurunkan motivasi kerja yang akan dilakukan oleh dosen, sebaliknya semakin menurun stres kerja yang terjadi pada diri dosen akan menyebabkan semakin meningkat motivasi yang timbul dalam diri dosen. Seorang dosen yang mengalami stres kerja biasanya akan menimbulkan respon fisik, psikologis dan gangguan perilaku dengan adanya gangguangangguan tersebut dengan sendirinya akan menyebabkan terjadi penurunan motivasi kerja dosen dalam melaksanakan pekerjaan, dosen menjadi kurang semangat, lesu dan tidak fokus dalam menjalankan tugasnya. Untuk membangkitkan kembali motivasi seorang dosen sangatlah diperlukan adanya penanggulangan/manajemen stres yang baik yang ada dalam diri dosen, pencegahan stres kerja jauh lebih efektif dari pada mengatasi stres kerja yang telah terjadi dengan mencegah dan mengatasi stres kerja yang timbul dalam diri dosen maka akan membangkitkan kembali motivasi kerjanya dan pada akhirnya akan berdampak pada peningkatan kinerja dosen.

Efektivitas manajerial langsung negatif terhadap stres kerja. Efektivitas manajerial berpengaruh langsung negatif terhadap stres kerja dosen kebidanan di provinsi Lampung, artinya semakin tepat efektivitas manejerial yang dilakukan oleh kaprodi akan menyebabkan penurunan stres kerja yang terjadi pada diri dosen, sebaliknya semakin tidak tepat efektivitas manejerial yang dilakukan kaprodi akan semakin meningkat stres kerja yang dialami oleh dosen. Hal ini diperkuat pendapat J Mullins (2005: 264) yang menyatakan ada empat kriteria efektivitas manajer dalam hubungannya dengan bawahannya dalam pencegahan dan penanggulangan stres kerja yaitu:

(1) the manager work, (2. the manager himself/herself, (3) the ${ }^{i}$ manager relationships with other people, (4) the manager as part of the organization, and (5) creterion of general effectiveness allocation of resources, achieving purpose, goal attainment, planning, organizing,coordinating, controlling.

Implikasinya bahwa kriteria efektivitas terdiri atas lima kriteria, empat bersifat khusus dan satu kriteria bersifat umum. Empat kriteria yang berkaitan dengan kehidupan manajer yaitu pada kriteria ketiga hubungan manajer dengan orang lain seperti dengan bawahan di antaranya adalah bagaimana seorang manajer dapat menangani dan mencegah konflik/ stres kerja yang terjadi pada diri karyawannya. Dari kajian di atas dapat disimpulkan bahwa semakin tepat kaprodi menjalankan fungsi efektivitas manajerialnya menyebabkan penurunan stres kerja pada dosen, baik dalam melalukan tugas pokoknya dalam bidang pendidikan dan pembelajaran, penelitian dan pengabdian pada masyarakat.

Self-efficacy berpengaruh langsung negatif terhadap stres kerja. Stres kerja dosen kebidanan di Provinsi Lampung, artinya semakin kuat self-efficacy yang dimiliki oleh dosen akan menyebabkan penurunan stres kerja yang terjadi pada diri dosen, sebaliknya semakin lemah self-efficacy yang ada dalam diri dosen akan menyebabkan semakin meningkat stres kerja yang dialami oleh dosen. Tanpa adanya keyakinan diri yang kuat dari seorang dosen dalam melaksanakan pekerjaan sehari-hari terutama dalam menjalankan tugas khusus yang menantang akan mengakibatkan stres kerja pada diri dosen 
akan semakin meningkat, oleh sebab itu sangat diperlukan usaha untuk meningkatkan keyakinan diri dalam diri dosen sehingga dapat menurunkan stres kerja yang timbul dalam diri dosen.

\section{PENUTUP}

Simpulan. Hasil penelitian ini memperkuat teori bahwa: (1) Perbaikan, peningkatan dan ketepatan efektivitas manajerial kaprodi dalam menjalankan peran dan fungsinya akan menyebabkan peningkatkan kinerja dosen. (2) peningkatan self efficacy yang kuat akan menyebabkan peningkatan kinerja dosen kebidanan di Provinsi lampung. (3) Stres kerja akan menyebabkan penurunan kinerja dosen kebidanan di Provinsi lampung. Stres kerja akan berdampak pada penurunan kinerja dosen, kinerja dosen kebidanan di Provinsi lampung. (4) Peningkatan motivasi kerja akan menyebabkan peningkatan kinerja dosen kebidanan di Provinsi lampung. dosen yang mempunyai tingkat motivasi yang tinggi cenderung memiliki kinerja yang tinggi. (5) Ketepatan efektivitas manajerial yang dilakukan kaprodi akan menyebabkan peningkatan motivasi kerja yang dialami dosen kebidanan di provinsi Lampung. (6) Penguatan self-efficacy akan menyebabkan peningkatan motivasi kerja dosen kebidanan di Provinsi lampung. (7) Stres kerja yang terjadi dalam diri dosen akan menyebabkan terjadinya penurunan motivasi kerja dosen. (8) Ketepatan efektivitas manajerial yang dilakukan kaprodi akan menyebabkan penurunan stres kerja yang dialami dosen. Kesembilan; untuk menurunkan stres kerja sangatlah diperlukan penguatan terhadap kepercayaan diri seseorang.

\section{DAFTAR RUJUKAN}

Bandura Albert. (1998) Self-efficacy The Exescise of Control. New York: Freeman and Company.

Craig C. Pinden. (2008) Work Motivation in Organizational Behavior. New York: McGraw, Hill

Colquitt, Lepine, Wesson. (2013) Organizational Behavior. New York: McGraw-Hill.

Gibson dan Ivancevich, et al. (2006) Organizational Behavior Structure Processes. Philipines: McGraw- Hill.

Harold Koontz and Cyril O’Donnell, (1995) Principles of Management, Sevent Edition. London: McGraw-Hill Book Company,Inc.

Ivancevich, Konopaske, Matteson. (2011) Organizational Behavor and Management. New York: McGraw Hill.

L. Daft Richard and Raymond A. Noe, (2001) Organizational Behavior, Florida: Harcourt College Publisher

Lourie J Mullins, (2005) Management and Organizational Behavior. seventh Edition Edinburgh Pearson Education Limited.

Luthans Fred, (2011) Organizational Behavior Twelfth Edition. New York: McGraw-Hill Companies, Inc.

M Jex Steven. (2002) Organitational Psychology a Scienlist Predictioner Approach New York; John Willey S\& Sons.

John W. Newstroom. (2007) Organizational Behavior: Human behavior at work, twelfth edition. New York: McGraw-Hill, 
Richmond. (1999) Mental Health Association. Sources of Workplace Stress. National Institute of Occupational Safety and Health.

Robbins Stephen P. \& Mary Coulter. (2012) Management. Elevent Edition. USA: Prentice Hall Inc.

Robert C Beck. (1990) Motivation Theories and Principles. New Jersey; PrenticeHall,Inc,

Robert Kreitner and Angelo Kinicki. (2010) Organizational Behavior, (New York: McGraw-Hill.

Rober L. Mathis and John H, Jackson. (2006) Human Resourcces Management Jakarta Salemba Empat \& Thomson South Western.

Schermerhorn/ Hunt/ Osborn/ Uhl-Bien. Organisational Behaviour An Asia-Pacific Perspective, New-York: America Copyright, 2010

Slocum and Helriegel. (2011) Principles of organizational behavior, 13th Ed. Canada: South western.

Steven Douglas Brown, Robert William Lent. (2005) Career Development and Counseling Putting Theory and Research to work. New York: Wiley judge.

Stephen P. Robbins dan David A. De Cenzo, (2009) Fundamental of Management. USA: Prentice Hall International.

Stephen P. Robbins, (2001) Organizational Behavior Concepts Contreversies an Application New Jersey, Prentice Hall. 
Efektivitas Manajerial, Self-Efficacy, Stres Kerja dan Motivasi... 